de nos connaissances, non seulement dans les aspects généraux de ces problèmes, mais dans ceux relatifs à la colonie. Il insiste sur les rapports entre alimentation et maladies; beaucoup de celles-ci sont dues à des carences qu'une alimentation rationnelle pourra aider à guérir, car elle permettra de rétablir les transformations chimiques qui doivent s'opérer dans les cellules en bonne santé, et de désintoxiquer les organes. Il faudra pour mener ces études à bien, de longues séries d'observations et de nombreuses recherches phytochimiques et biologiques. Elles ne pourront être couronnées de succès, conclut l'auteur, que par une collaboration de spécialistes de disciplines différentes, travaillant d'aptès un plan unique, mûrement étudié, et des méthodes capables de fournir des résultats comparables. (Communication du Professeur N. De Cleene.)

\title{
Suspension of the Prize Competition for Books in African Languages.
}

IN view of present circumstances it has been decided to suspend for the time being the annual Prize Competition for books in African languages. The manuscripts which have been received for the tenth competition, in HeheBena and Tiv (Munshi), are being kept at the London office until it is possible to arrange for the resumption of the competition. The competition in Luo and the Herero-Kwanyama-Ondongo group, the languages selected for 1940 by the Executive Council at its last meeting, will be held as soon as circumstances permit. The following note surveys the results of the Prize Competition since its inception and draws attention to the number of African manuscripts which have not been published.

\section{Unpublished Manuscripts in African Languages.}

THE annual Prize Competition of the Institute has now included more than thirty languages. The following survey gives the names of the languages and the number of manuscripts received in each.

$\begin{array}{lccc}1930 & \text { Entries } & 1932 & \text { Entries } \\ \text { Xhosa } & \text { I3 } & \text { Nyanja } & \text { I3 } \\ \text { Swahili } & 19 & \text { Ibo } & 21 \\ \text { Hova } & 6 & \text { Zulu } & \text { I4 } \\ \text { Akan (Twi or Fante) } & 5 & \text { Ewe } & 29 \\ & & \text { Bulu } & \text { II } \\ \text { I93I } & & & \\ \text { Mende } & \text { I } & & \\ \text { Suto } & \text { I5 } & \text { I933 } & \text { I9 } \\ \text { Ganda } & 9 & \text { Yoruba } & 9 \\ \text { Mandingo } & 2 & \text { Chuana } & \text { I2 } \\ \text { Hausa } & \text { I0 } & \text { Kikuyu } & \end{array}$


1934

Duala

Shambala

Shona

1935

Thonga Cluster

Shilluk

Luba

NOTES AND NEWS

Entries

23

10

2

2
None
3

1936

$\mathrm{Ga}$ and Adanme

Ila-Tonga-Mukuni

1937

Venda

Ruanda

Efik

1938

Bemba

Nkundo-Mongo
Entries

23

8

4

None

6

8

8

The object of the Competition is to stimulate the interest of Africans in their own languages and to increase the amount of reading matter available for the literate African.

The awards are made on the recommendation of a sub-Committee appointed by the Council of the Institute, on the basis of reports submitted by experts in the languages in question. One first prize of $£ 20$ and one second prize of $f 10$ is offered for each language every year, and a number of consolation prizes of books are also awarded. The manuscripts received are classified into five categories, but so far no manuscript has been placed in Class $\mathbf{I}$ as the Council is anxious to keep the standard of the Competition high. About fifty per cent. of the entries reach the standard required for Classes 2 and 3 .

The examiners' reports give an excellent description of each manuscript and would form an admirable basis for a statement on the value of the literary productions achieved by Africans.

The primary aim of the Competition, namely the stimulation of vernacular literature, has only to a modest degree been reached. Our information about the manuscripts which have been published is incomplete, but as far as we know the following have appeared:

Nyanja

'Man of Africa', by Samuel Ntara.

'A Nyanja Story', by Walters S. Saukila, annotated by A. Werner. Ene

'Toko Atolia', by F. K. Fiawoo.

Ibo

Various competitors.

Ila

Translation of 'Pilgrim's Progress', by Moses Mubitana.

\section{How published}

In an English translation by Mr. Cullen Young.

In English as a supplement to the Zeit schrift für Eingeborenensprachen.

Appeared in Germany in the Mitteilungen des Seminars für orientalische Sprachen, 1937, in German and Ewe.

Material used by S. Nigerian Education Department for four school readers.

Published by United Society for Christian Literature. 


\section{Shambala}

' Ukale wa Washambala ' (History and Customs of the Shambala), by Samweli Shauli.

\section{Swahili}

'Uhuru wa Watumwa' (The Slaves who were brought to Freetown), by James Mbotela.

Yoruba

'Yoruba Oracles and their Modes of Divination', by T. A. J. Ogunbiyi.

Venda

'Ngoma Lungundo ', by Ernst Mudau.

\section{Bulu}

'Nnanga Kôn', by Njemba Medu.
Translated into Swahili for inclusion in the Baranza collection of the Bethel Mission.

Published by S.P.C.K.

Published by C.M.S. Bookshop, Lagos.

To be published as a supplementary school reader.

Published by the American Protestant Mission at Yaoundé. Mav be followed by others

This is a small percentage of the sum total. Some of the material is of an anthropological character and might be published, either together with a translation in a European language, or in translated form only, in scientific journals, as has actually been done in a number of cases. These manuscripts give much fresh ethnographical information, which is not always easily accessible to the European investigator, and it would be a pity if it were for ever to be buried in an archive or in the modest dwelling of an African teacher, exposed to the ravages of a tropical environment. The same is true of a considerable number of other manuscripts, biographies, historical scenes, customs, pure fiction, and also translations of European books; many of them would provide a valuable addition to African literature if only the means for publishing could be found.

We are anxious to draw the attention of our readers to these facts and should be grateful if those among them who are interested in the publication of manuscripts of one or the other category would help in encouraging African authors, for the best encouragement we can give them is to make their works available to a reading public.

\section{Monographs on Social Anthropology}

THE London School of Economics is about to inaugurate a series of Monographs on Social Anthropology, in which it is hoped to make available to the scientific public field-work data of a detailed nature such as would not readily find a commercial market. The first volume in the series, 'The Work of the 